\title{
Kekuatan Lengan dan Keseimbangan Terhadap Kemampuan Handstand Atlet Daradaeng Gymnastic Club
}

\author{
Ariana Asri , Suparman, Haeril \\ Program Studi Pendidikan Jasmani, Kesehatan, dan Rekreasi STKIP YPUP Makassar \\ ariana.asri1401@gmail.com
}

Received: Januari 2021; Accepted: Februari 2021; Published: Maret 2021

Ed: Maret 2021; 8(1): 1-7

\begin{abstract}
Abstrak
Penelitian ini bertujuan untuk mengetahui hubungan kekuatan lengan dan keseimbangan terhadap kemampuan Handstand. Penelitian ini bersifat deskriptif dengan dua variabel bebas yaitu kekuatan lengan dan keseimbangan dengan satu variabel terikat yaitu kemampuan Handstand. Sampel penelitan ini adalah atlit Club Senam Daradaeng Makassar sebanyak 20 orang. Teknik analisis data yang digunakan adalah analisis deskriptif, analisis koefisien korelasi pada taraf signifikan 0,05, dengan menggunakan bantuan komputer melalui program SPSS. Hasil penelitian menunjukkan : (1) Ada kontribusi yang signifikan antara kekuatan lengan dengan kemampuan Handstand adalah atlit Daradaeng Gymanstic Club Makassar dengan nilai R Squares sebesar 0,758 (2) Ada kontribusi yang signifikan antara keseimbangan dengan kemampuan kemampuan Handstand atlit Daradaeng Gymanstic Club Makassar dengan nilai R Squares sebesar 0,758 (3) Ada kontribusi yang signifikan antara kekuatan lengan dan keseimbangan secara bersama-sama dengan kemampuan Handstand mahasiswa penjaskesrek dengan nilai (R)sebesar 0,852 dan nilai Fhitung (F) sebesar 48,816.
\end{abstract}

Kata Kunci: Kekuatan lengan ; Keseimbangan; Kemampuan Handstand.

\begin{abstract}
This study aims to determine the relationship between arm strength and balance on handstand ability. This research is descriptive with two independent variables, namely arm strength and balance with one dependent variable, namely handstand ability. The sample of this research is the athletes of the Makassar Daradaeng Gymnastics Club as many as 20 people. The data analysis technique used is descriptive analysis, correlation coefficient analysis at a significant level of 0.05, using computer assistance through the SPSS program. The results showed: (1) There was a significant contribution between arm strength and Handstand ability, namely Daradaeng Gymanstic Club Makassar athlete with an $R$ Squares value of 0.758 (2) There was a significant contribution between balance and Handstand ability of Daradaeng Gymanstic Club Makassar athlete with an $R$ value. Squares of 0.758 (3) There is a significant contribution between arm strength and balance together with the Handstand ability of Physical Education students with a value $(R)$ of 0.852 and an Fcount $(F)$ of 48.816.
\end{abstract}

Keywords: arm strength; Balance; Handstand Ability.

\section{PENDAHULUAN}

Senam merupakan aktifitas uji diri yang berguna untuk mencapai tujuan tertentu, antara lain keberanian, kesenangan, kosentrasi, kepercayaan diri yang muncul dari keterlibatan mereka dalam melakukan gerakan. Jadi senam adalah suatu latihan tubuh yang diciptakan secara sistematis dan teratur. Menurut Andriyani Fis (2012:8) Senam Lantai merupakan salah satu rumpun senam. Hal itu disesuaikan dengan namanya yaitu lantai. Yang dimaksut untuk latihan menggunakan matras ataupun permadani. Mucholid (2007:82) mengemukakan bahwa Senam 
Lantai merupakan salah satu bentuk senam ketangkasan yang dilakukan di matras dan tidak menggunakan peralatan khusus.

Handstand merupakan sikap berdiri dengan kedua tangan, berarti kedua belah telapak tangan bertindak sebagai tumpuan Sumpeno ( 2010:75) . Beberapa gerakan yang dilakukan dalam handstand mengayunkan kaki, melompat, mengangkat, dan mendorong. Keseimbangan dan kekeuatan sangat diperlukan dalam melakukan handstand.

Menurut Harsono (2018:164) Blance atau keseimbangan ialah kemampuan untuk mempertahankan system neuromuscular (system saraf-otot) kita dalam kondisi statis, atau mengontrol system saraf otot agar tidak jatuh atau roboh; atau kemampuan untuk mempertahankan system neuromuscular kita dalam kondisi statis, atau mengonrol system neuromuscular terseut dalam satu posisi atau sikap yang efisien selagi kita bergerak. Menurut Widiastuti (2017:161), Keseimbangan adalah kemampuan mempertahankan sikap dan posisi tubuh secara tepat pada saat berdiri (static balance) atau pada saat melakukan gerakan (dynamic balance). Kemampuan untuk mempertahankan keseimbangan dipengaruhi oleh beberapa faktor antara lain: visual, telinga (rumah siput). menurut Fenamlampir (2015:165), Menjelaskan terdapat dua macam keseimbangan yaitu keseimbangan statis dan dinamis, keseimbangan statis adalah kemampuan mempertahankan keadaan seimbang dalam keadaan diam, sedangkan kesimbangan dinamis adalah kemampuan mempertahankan keadaan seimbang dalam keadaan bergerak, misalnya berlari berjalan, melambung dan sebagainya. Kualitas keseimbangan dinamis tergantung pada mekanisme dalam saluran semisirkular, persepsi kinestetik, tendon dan persendian, persepsivisual selama melakukan gerakan dan kemampuan koodinasi.

Menurut Widiastuti (2015:15) secara fisiologis kekuatan otot adalah kemampuan otot atau sekelompok otot untuk melakukan satu kali kontraksi secara maksimal melawan tahanan atau beban. Secara mekanisme kekuatan otot lengan didefinisikan sebagai gaya (force) yang dapat oleh otot atau sekelompok otot dalam suatu kontraksi maksimal, kekuataan otot merupakan hal yang penting untuk setiap orang.

\section{METODE}

Metode peenelitian yang digunakan adalah penelitian kuantitatif. Sugiyono (2016: 15) metode kuantitatif dapat diartikan sebagai metode penelitian yang berlandasan pada filsafat positivism, digunakan untuk meneliti pada populasi atau sampel tertentu, pengumpulan data mengunakan instrument penelitian, analisis data bersifat kuantitatif/statistik, dengan tujuan untuk menggambarkan dan menguji hipotesis yang telah ditetapkan. Penelitian ini adalah jenis penelitian ini yang bersifaat deskriptif yang bertujuan untuk mengetahui ada tidaknya Hubungan Kekuatan Otot Lengan Dan Keseimbangan Terhadap Kemampuan Handstand. Dengan dengan demikian model desain penelitian yang digunakan secara sederhana dapat dilihat pada gambar sebagai berikut. 


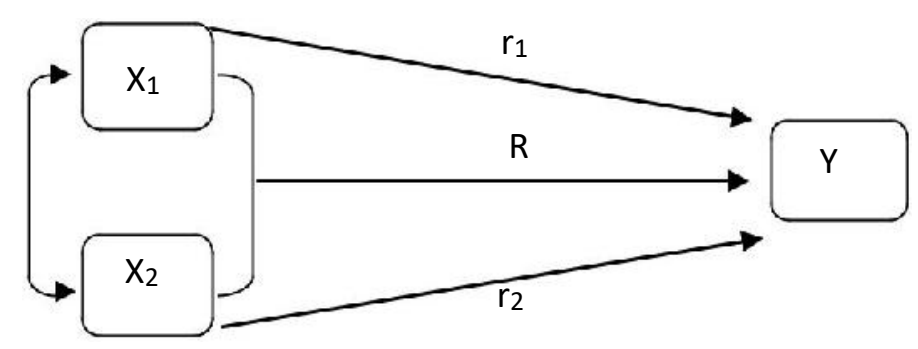

Gambar 1. Model desain penelitian

Keterangan:

Sumber : Metode Penelitian, Sugiyono (2010:68)

$\mathrm{X}_{1}$ : Kekuatan Lengan

$\mathrm{X}_{2} \quad$ : Keseimbangan

Y : Kemampuan Handstand

Populasi yang dipergunakan dalam penelitian ini adalah atlet Daradaeng Gymnastic Club yang jumlah populasinya terbatas hanya 20 orang, maka semuanya menjadi sampel penelitian. Oleh sebab itu dalam penelitian ini jumlah total sampelnya sebanyak 20 orang

\section{HASIL DAN PEMBAHASAN}

Data empiris yang diperoleh di lapangan melalui hasil tes dan pengukuran yang terdiri atas, kekuatan lengan, keseimbangan dan kemampuan Handstand Atlet Daradaeng Gymnastic Club Makassar selanjutnya dianalisis dengan menggunakan teknik statistik deskriptif dan statistik inferensial. Analisis data secara deskriptif dimaksudkan untuk mendapatkan gambaran umum data penelitian, kemudian dilanjutkan dengan pengujian persyaratan analisis yaitu uji normalitas data. Sedangkan analisis data secara inferensial dimaksudkan untuk mendapatkan hasil pengujian hipotesis yang diajukan dalam penelitian ini.

\section{Analisis Deskriptif}

Deskripsi data dari hasil penelitian bertujuan untuk memberikan gambaran umum mengenai penyebaran distribusi kekuatan lengan dan keseimbangan dan kemampuan Handstand Atlet Daradaeng Gymnastic Club Makassarc baik berupa ukuran letak distribusi frekuensi. Rangkuman hasil perhitungan statistik deskripsi tersebut dikemukakan sebagai berikut

\section{Tabel 1. Rangkuman Hasil Penelitian}

\begin{tabular}{lccccccc} 
& N & Sum & Mean & Stdv & Range & Min. & Max. \\
\hline $\begin{array}{l}\text { Kekuatan } \\
\text { Lengan }\end{array}$ & 20 & 754 & 37,70 & 7,027 & 20 & 27 & 47 \\
\hline Keseimbangan & 20 & 441 & 22,05 & 3,605 & 13 & 15 & 28 \\
\hline $\begin{array}{l}\text { Kemampuan } \\
\text { Handstand }\end{array}$ & 20 & 172 & 8,60 & 1,046 & 3 & 7 & 10 \\
\hline
\end{tabular}




\section{Uji Normalitas Data}

Oleh karena pengolahan data dalam penilaian ini menggunakan uji statistik dengan regresi, maka perlu dilakukan uji persyaratan analisis. Adapun uji persyaratan yang dimaksud adalah uji normalitas dengan menggunakan uji Kolmogorov Smirnov.

Tabel 2. Rangkuman Hasil Uji Normalitas Kolmogorov Smirnov

\begin{tabular}{llll} 
Variabel & $\mathbf{P}$ & $\boldsymbol{\alpha}$ & Ket \\
\hline Kekuatan Lengan & 0,731 & 0,05 & Normal \\
\hline Keseimbangan & 0,512 & 0,05 & Normal \\
\hline Kemampuan Handstande & 0,304 & 0,05 & Normal \\
\hline
\end{tabular}

Hipotesis yang diajukan dalam penelitian ini perlu diuji dan dibuktikan melalui data empiris yang diperoleh di lapangan melalui tes dan pengukuran terhadap variabel yang diteliti. Karena data penelitian mengikuti sebaran normal, maka untuk menguji hipotesis penelitian ini digunakan analisis statistik parametrik dengan menggunakan teknik analisis regresi.

\section{Uji Liniearitas Data}

Karena data penelitian ini mengikuti sebaran normal, maka untuk menguji hipotesis penelitian ini digunakan analisis statistik parametrik dengan menggunakan analisis linearitas. Analisis linearitas bertujuan untuk mengetahui apakah dua variabel mempunyai hubungan yang linear atau tidak linear secara signifikan. Salah satu persyaratan suatu data dikatakan linear apabila Pvalue lebih besar dari $\alpha 0,05$ (Pvalue $>0,05$ ). Adapun hasil linearitas antar variabel dalam penelitian ini adalah sebagai berikut:

Tabel 3. Rangkuman Hasil Uji Linieritas

\begin{tabular}{llll} 
Variabel & $\mathbf{P}$ & $\boldsymbol{\alpha}$ & Ket \\
\hline $\begin{array}{l}\text { Kekuatan Otot Tungkai } \\
\text { Terhadap Kemampuan } \\
\text { Handstand }\end{array}$ & 0,867 & 0,05 & Linear \\
\hline $\begin{array}{l}\text { Keseimbangan terhadap } \\
\text { Kemampuan Handstand }\end{array}$ & 0,700 & 0,05 & Linear \\
\hline
\end{tabular}

\section{Hasil Pengujian Hipotesis}

a. Karena data penelitian ini mengikuti sebaran normal dan memiliki hubungan atau linear, maka untuk menguji hipotesis penelitian ini digunakan analisis statistik parametrik. Hasil pengujian kontribusi kekuatan otot lengan terhadap kemampuan Handstand. 
Tabel 4. Hasil Uji Hipotesis melalui Analisis Regresi Sederhana

\begin{tabular}{|c|c|c|c|}
\hline Variabel & $\mathbf{r}$ & $\mathbf{R}$ & $\mathbf{P}$ \\
\hline Kontribusi Kekuatan & & & \\
\hline $\begin{array}{l}\text { Otot Lengan }\left(\mathrm{X}_{1}\right) \\
\text { terhadap Kemampuan } \\
\text { Handstand }(\mathrm{Y})\end{array}$ & 0,870 & 0,758 & 0,000 \\
\hline
\end{tabular}

b. Hasil pengujian keseimbangan terhadap kemampuan Handstand.

Tabel 5. Hasil Uji Hipotesis melalui Analisis Regresi Sederhana

\begin{tabular}{lllll} 
Variabel & $\mathbf{r}$ & $\mathbf{R}$ & $\mathbf{P}$ & Ket \\
\hline $\begin{array}{l}\text { Keseimbangan }\left(\mathbf{X}_{\mathbf{2}}\right) \\
\begin{array}{l}\text { terhadap Kemampuan } \\
\text { Handstand }(\mathbf{Y})\end{array}\end{array}$ & 0,871 & 0,758 & 0,000 & Sig
\end{tabular}

c. Hasil pengujian kontribusi kekuatan otot tungkai, kecepatan reaksi tangan, dan kelentukan pergelangan tangan secara bersama-sama terhadap kemampuan ketepatan pukulan forehand drive.

Tabel 6. Hasil Uji Hipotesis melalui Analisis Regresi Sederhana

\begin{tabular}{llllll} 
Variabel & r & R & P & Ket & \\
\hline $\begin{array}{l}\text { Kontribusi Kekuatan otot } \\
\text { lengan }\left(\mathbf{X}_{1}\right) \text {, }\end{array}$ & & & & & \\
$\begin{array}{l}\text { keseimbangan }\left(\mathbf{X}_{2}\right), \\
\text { terhadap Kemampuan } \\
\text { Handstand }\end{array}$ & 0,923 & 0,852 & 0,000 & Sig \\
\hline
\end{tabular}

Dari hasil pengujian hipotesis pertama dapat dikemukakan bahwa ada kontribusi yang signifikan kekuatan otot lengan terhadap kemampuan handstand atlet Daradaeng Gymnastic Club. Hal ini dapat diketahui dari hasil analisis diperoleh nilai koefisien korelasi $(\mathrm{r})=0,870 \mathrm{dan} \mathrm{p}$-value $=$ $0,000<0,05$. Hal ini berarti H0 ditolak dan H1 diterima. Dengan demikian, koefisien korelasi berarti atau signifikan. Sedangkan pada analisis koefisien determinasi (R Square) diperoleh nilai sebesar 0,758 yang berarti 75,8\% dari variabel kemampuan handstand atlet Daradaeng Gymnastic Club (Y) disebabkan oleh kekuatan otot lengan (X1). Hal ini berarti 75,8\% data kekuatan otot lengan (X1) memberikan kontribusi langsung terhadap kemampuan handstand atlet Daradaeng Gymnastic Club (Y). Apabila hasil penelitian ini dikaitkan dengan pendapat Sukadiyanto dan Dangsina (2011:90) kekuatan otot merupakan salah satu komponen dasar biomotor yang diperlukan dalam setiap cabang olahraga. Secara sederhana kekuatan dapat diartikan sebagai kemampuan untuk memberikan tenaga terhadap tekanan. Seorang atlet senam harus memiliki 
kekuatan fisik salah satunya adalah kekuatan oto lengan. Maka dapat disimpulkan untuk dapat melaksanakan kemampuan handstand, unsur kekuatan otot lengan sangatlah berperan untuk menopang tubuh pada saat tumpuan berada pada kedua tangan.

Dari hasil pengujian hipotesis kedua dapat dikemukakan bahwa ada kontribusi yang signifikan keseimbangan terhadap kemampuan handstand atlet Daradaeng Gymnastic Club. Hal ini dapat diketahui dari hasil analisis diperoleh nilai koefisien korelasi $(r)=0,871$ dan $p$-value $=0,000$ $<0,05$. Hal ini berarti H0 ditolak dan H1 diterima. Dengan demikian, koefisien korelasi berarti atau signifikan. Sedangkan pada analisis koefisien determinasi (R Square) diperoleh nilai sebesar 0,758 yang berarti 75,8\% dari variabel kemampuan handstand (Y) disebabkan oleh keseimbangan (X2). Hal ini berarti 75,8\% data keseimbangan (X2) memberikan kontribusi langsung terhadap kemampuan handstand atlet Daradaeng Gymnastic Club (Y). Apabila hasil penelitian ini dikaitkan dengan pendapat kertamanah (2015:62) dengan keseimbangan dapat mempertahankan keadaan tubuh dalam keadaan diam, . Dengan demikian, memudahakan tubuh untu menjaga keseimbanganya pada saat kedua tangan bertumpu pada matras yang dimana titik berat badan berada pada kedua tanagan. Maka dapat disimpulkan bahwa apabila seorang atlet memiliki keseimbangan yang baik maka akan mampu melakukan gerak handstand.

Dari hasil pengujian hipotesis ketiga dapat dikemukakan bahwa ada kontribusi yang signifikan kekuatan otot lengan dankeseimbangan terhadap kemampuan handstand atlet Daradaeng Gymnastic Club. Hal ini dapat diketahui dari hasil analisis diperoleh nilai koefisien korelasi $(\mathrm{r})=$ 0,923 dan p-value $=0,000<0,05$. Hal ini berarti H0 ditolak dan H1 diterima. Dengan demikian, koefisien korelasi berarti atau signifikan. Sedangkan pada analisis koefisien determinasi (R Square) diperoleh nilai sebesar 0,852 yang berarti $85,2 \%$ dari variabel kemampuan kemampuan handstand atlet Daradaeng Gymnastic Club (Y) disebabkan oleh kekuatan otot lengan (X1), keseimbangan (X2). Hal ini berarti 85,2\% data kekuatan otot lengan (X1), keseimbangan (X2) secara bersamasama memberikan kontribusi langsung terhadap kemampuan handstand (Y) dan sisanya 14,2\% atau $(100 \%-85,2 \%)=14,4 \%)$. Disebabkan oleh faktor-faktor lain yang tidak temasuk dalam penelitian ini. Apabila hasil penelitian ini dikaitkan dengan pendapat John ( 2014: 7 ), bahwa "berdiri dengan tangan merupakan suatu keterampilan keseimbangan yang membutuhkan kekuatan tubuh bagian atas yang kuat dan bahu yang lentur. Gerakan ini dimulai dengan sikap seperti akan berlari, jari menghadap kedepan dan bahu direngangkan. Ayunkanlah satu kaki lurus ke atas, dan hentakkan kaki yang lain. Satuhkanlah kedua kaki kamu, jagahlah kedua tangan tetap lurus. Pada posisi berdiri dengan tangan ini, kepala harus tetap tegak, bahuh diluruskan, jari kaki lurus keatas. Kamu pun bisa menarik garis lurus dari ujung jari kaki, bahu sampai ketangan. Untuk menjaga kesimbangan dalam sikap berdiri dengan tangan ini, pindahkan berat badan dengan menekankan ujung jari bila kamu akan jatuh (over balancing). Handstand yang kurang seimbang (underbalanced) dapat diperbaiki dengan bertumpu pada telapak tangan dan memindahkan berat badan kedepan. .Jadi dapat disimpulkan bahwa untuk dapat melakukan gerak handstand sangat dibutuhkan kekuatan otot lengan menopang tubuh, disertai dengan keseimbangan sehingga dapat menjaga keseimbangan badan ketika dalam keadaan badan bertumpu pada kedua tangan.

\section{KESIMPULAN}

Kesimpulan yang dapat ditarik dalam penelitian ini, berdasarkan data penelitian dan sesuai dengan hasil analisis pengujian hipotesis,maka kesimpulan adalah Terdapat kontribusi yang signifikan kekuatan lengan terhadap kemampuan handstand Atlet Daradaeng Gymnastic Club Makassar.Terdapat kontribusi yang signifikan keseimbangan terhadap kemampuan handstand 
Atlet Daradaeng Gymnastic Club Makassar dan terdapat kontribusu yang signifikan antara kekuatan lengan dan keseimbangan secara bersama-sama terhadap kemampuan handstand Atlet Daradaeng Gymnastic Club Makassar. Maka dapat dikatakan bahwa kekuatan lengan dan keseimbangan mampu meningkatkan kemampuan Handstand pada pembelajaran senam lantai.

\section{DAFTAR PUSTAKA}

Achmad Sofyan Hanif. 2017. Falsafah, Pengukuran Dan Teknik Dasar Shorinji Kempo. Jakarta: Rajawali Pers.

Andriyani, Fis. 2012. Dr. Olahraga Menjelaskan Senam Lantai. Jakarta: Balai Pustaka.

Agus Mukholid. 2007. Pendidikan Jasmani Olahraga dan Kesehatan. Jakarta timur: Yusdistira

Farut Muhyi Muhammad Fenanlampir Albertus. Tes \& Pengukuran Dalam Olahraga. Yogyakarta: CV Andi Offset, 2015.

Fredericus Suharjana 2011. Jurnal Pendidikan Jasmani Indonesia. Diterbitkan Oleh: Jurusan Pendidkan Olahraga Fakultas Ilmu Keolahragaan Universitas Negeri Yogyakarta.

John Dan Mary Jean Treatta. 2014. Dasar-Dasar Senam. Penerbit Angkasa, Jln Cipagalo Girang No. 24, Margacina-Bandung.

Joko Sumpeno Dan Dedy Joko Budi Santoso. 2010. Pendidikan Jasmani, Olahraga, Dan Kesehatan. Jakarta: Pusat Perbukuan, Kementrian Pendidikan Nasional.

Sugiyono, 2010. Metode penelitian kuantitatif. Bandung: Alvabeta. CV.K

Sapto Adi, 2018. Bentuk-Bentuk Gerakan Senam. Universitas Negeri Malang Fakultas Ilmu Keolahragaan Sukadiyanto dan Dangsina Muluk. (2011). Pengantar Teori dan Metodologi Melatih Fisik. Bandung: Lubuk Agung

Sapto Adi, 2018. Bentuk-Bentuk Gerakan Senam. Universitas Negeri Malang Fakultas Ilmu Keolahragaan

Halim, Nur Ichsan. 2011. Tes Dan Pengukuran Kesegaran Jasmani. Makassar: Badan Penerbit Universitas Negeri Makassar.

Harsono .2018.Latihan Kondisi Fisik.Pt Remaja Rosdakarya.Bandung

Widiastuti. 2015. Tes Dan Pengukuran Olahraga. Jakarta. PT Bumi Timur Jaya.

Widiastuti. 2017. Tes Dan Pengukuran Olahraga. Jakarta: Pt Raja Grafindo Persada, 